\author{
Romuald Rydz \\ Uniwersytet im. Adam Mickiewicza w Poznaniu
}

DOI: $10.19195 / 2450-274 X .3 .9$

\title{
Kontrrewolucyjna idea Europy. Rozważania Edmunda Burke'a o tożsamości europejskiej
}

Abstrakt: 1 listopada 1790 r. w Londynie został opublikowany jeden z najważniejszych tekstów osiemnastowiecznej brytyjskiej myśli politycznej. Autorem dzieła znanego pod skróconym tytułem jako Rozważania o rewolucji we Francji był Edmund Burke - jeden z najbardziej znanych wigowskich posłów zasiadających w Izbie Gmin.

Choć Burke w Rozważaniach występował przede wszystkim jako obrońca brytyjskiego porządku i zwyczaju politycznego, to zarówno w tym dziele, jak i wielu następnych tekstach można zauważyć, że przedmiotem jego troski była także wspólnota europejska. Wydaje się, że autor Rozważań jako jeden z pierwszych przedstawicieli ówczesnego świata polityki dostrzegł w rewolucyjnej gorączce rozprzestrzeniającej się z Paryża groźbę dla całej Europy. Owo niebezpieczeństwo Burke porównywał, z jednej strony, do fali barbarzyństwa, która zalała Rzym i zniszczyła cywilizację antyczną w okresie wędrówki ludów, z drugiej zaś - przypisywał mu cechy rewolucji religijnej, podobnej do tej, która podzieliła kontynent w XVI i XVII stuleciu. Było to więc w jego opinii podwójne zagrożenie, które mogło zniszczyć zarówno podstawy materialne Europy, jak i jej kościec kulturowy.

Słowa kluczowe: Europa, Edmund Burke, rewolucja francuska, konserwatyzm, Wielka Brytania, filozofia polityczna

\section{A counter-revolutionary idea of Europe. Edmund Burke's reflections on European identity}

Abstract: On 1st November 1790, one of the most important texts of the 18th century British political thought was published in London. The author of the work, known under the shortened title as Reflections on the Revolution in France, was Edmund Burke, one of the best-known Whigs sitting in the House of Commons.

Although in Reflections Burke was above all a defender of the British order and political custom, it can be noticed, both in this work and many subsequent texts, that he was also concerned for European community. It seems that the author of Reflections was among the first representatives of the 
world of politics at that time who viewed the revolutionary fever that was spreading from Paris as a threat to the whole Europe. Burke compared this danger, on the one hand, to the Barbarian wave that had flooded Rome and destroyed the antique civilisation in the Migrations Period, while on the other hand he ascribed it characteristics of a religious revolution, similar to the one that divided the continent in the 16th and 17th centuries. Thus, it was, in his opinion, a double threat. It could destroy both the material foundations of Europe and its cultural core.

Keywords: Europe, Edmund Burke, French Revolution, conservatism, Great Britain, political philosophy

1 listopada 1790 r. w Londynie został opublikowany jeden z najważniejszych tekstów osiemnastowiecznej brytyjskiej myśli politycznej. Autorem dzieła znanego pod skróconym tytułem jako Rozważania o rewolucji we Francji ${ }^{1}$ był Edmund Burke - jeden z przywódców zasiadającej w Izbie Gmin opozycji. Publikacja bardzo szybko spotkała się z ogromnym zainteresowaniem angielskiej opinii publicznej, a reakcje na nią zapoczątkowały debatę, w którą zaangażowały się najważniejsze postacie ówczesnego brytyjskiego życia politycznego i kulturalnego ${ }^{2}$. O takim przyjęciu dzieła zadecydowały zapewne osoba autora, lecz także podjęta tematyka.

W wypadku pierwszej okoliczności zwracano uwagę na to, że głos zabrał jeden z najznamienitszych wigowskich mówców parlamentarnych, znany do tej pory przede wszystkim ze swych krytycznych wystąpień wymierzonych w brytyjski establishment polityczny. To właśnie w nich Burke dał się poznać jako zdecydowany krytyk poczynań rządu angielskiego wobec kolonii amerykańskich ${ }^{3}$, rzecznik pozbawionych praw politycznych irlandzkich katolików czy też oskarżyciel byłego gubernatora Indii - Warrena Hastingsa. W angielskich kręgach radykalnych uchodził za przeciwnika politycznych planów Jerzego III, zmierzających do ograniczenia uprawnień parlamentu brytyjskiego oraz za entuzjastę zasad wolnorynkowych w ekonomii. Krótko mówiąc, można stwierdzić, że wedle ówczesnych standardów głos zabrał zadeklarowany zwolennik wolności, któremu powszechnie przypisywano liberalne sentymenty ${ }^{4}$.

${ }^{1}$ Pełny tytuł dzieła wskazywał, że jego tematem są nie tylko wydarzenia francuskie, ale ma ono charakter szerszy. W tłumaczeniu na język polski brzmi on: Rozważania o rewolucji we Francji i o debatach pewnych towarzystw londyńskich związanych z tym wydarzeniem, wyrażone w liście, który miat zostać wystany do pewnego gentelmana w Paryżu.

2 Szerzej na ten temat zob. E. Małłek, Wojna pamfletów w Anglii 1790-1793: wokół traktatu Edmunda Burke'a Reflections on the revolution in France, Toruń 1993.

3 Burke na początku konfliktu z kolonistami angielskimi w Ameryce Północnej opowiadał się za ugodą uwzględniającą interes mieszkańców kolonii, a następnie w dalszej fazie sporu za przyznaniem im pełnej niepodległości. Szerzej o poczynaniach Burke’a zob. F.P. Lock, Edmund Burke, t. 1. 1730-1784, Oxford 1998, s. 350.

4 Burke na płaszczyźnie obyczajowej uchodził za obrońcę tolerancji, ponieważ postulował m.in. likwidację kar dla homoseksualistów. Na liberalny charakter zapatrywań Burke’a zwraca uwagę np. Conor Cruise O’Brien w pracy The Great Melody: A Thematic Biography and Commented Anthology of Edmund Burke, London 1992. 
Jeśli chodzi o drugą okoliczność, należy podkreślić, iż dzieło Burke’a było pierwszą na Wyspach Brytyjskich publikacją, w której autor usiłował w sposób dogłębny poddać refleksji wydarzenia we Francji oraz przewidzieć ich konsekwencje zarówno dla obywateli Zjednoczonego Królestwa, jak i dla mieszkańców Europy. Warto przy tym zauważyć, że do tego momentu znacząca część angielskiej opinii publicznej postrzegała wypadki paryskie jako ograniczone wyłącznie do Francji. Wielu Brytyjczyków, przywiązanych do zdobyczy Glorious Revolution, sądziło ponadto, że Francja latem 1789 r. wkroczyła na drogę politycznych przekształceń, które miały miejsce w ich kraju sto lat wcześniej, i dlatego poczynania paryskich reformatorów budziły, szczególnie w kręgach radykalnych polityków oraz dysydentów religijnych, sporo sympatii. Pojawiały się nawet opinie, że francuscy rewolucjoniści, dążąc do urzeczywistnienia ideałów politycznej wolności i równości, wyprzedzili na tym polu obywateli Zjednoczonego Królestwa; zatem ci powinni, podążając śladem swych rewolucyjnych sąsiadów, na nowo podjąć dzieło reformowania życia politycznego we własnym kraju.

Rozpatrując reakcje Burke’a na polityczne wstrząsy w Paryżu, można dostrzec, iż już pierwsze informacje ten temat wzbudziły w nim daleko idącą rezerwę co do celów i charakteru rozwijającego się ruchu ${ }^{5}$. Natomiast wezwania do naśladowania francuskich rewolucjonistów uznał prawie natychmiast za swego rodzaju szaleństwo. W jego mniemaniu akceptacja francuskich wzorów stanowiła ogromne niebezpieczeństwo dla uformowanego w ciągu wielu wieków brytyjskiego systemu społeczno-politycznego. Ich realizacja niechybnie doprowadziłaby, jego zdaniem, do zaprzepaszczenia tego, co było w nim najcenniejsze, oraz skutkowałaby powszechnym chaosem i zniszczeniem. Owa obawa zapewne stanowiła decydującą przyczynę, która skłoniła wigowskiego polityka do zabrania głosu na temat dokonującej się we Francji rewolucji. Oprócz przeciwstawienia się jej hasłom dokonał on w swym dziele analizy oraz krytyki leżącej u jej podłoża tradycji intelektualnej, chcąc ukazać fałsz tkwiący w jej założeniach.

Choć Burke w Rozważaniach występował przede wszystkim jako obrońca brytyjskiego porządku i zwyczaju politycznego, to zarówno w tym tekście, jak i wielu następnych pismach można zauważyć, że przedmiotem jego troski była także wspólnota europejska ${ }^{6}$. Co ciekawe, trwałość owej wspólnoty budziła niepokój Burke’a znacznie wcześniej. Dał tego dowody na początku lat 70. XVIII stulecia, gdy na łamach Annual Register zastanawiał się nad skutkami rozbiorów Polski. Wtedy brytyjskiego polityka niepokoiły przede wszystkim apetyty państw zabor-

5 Powszechnie przyjmuje się, że wymuszone na Ludwiku XVI i jego rodzinie przenosiny z Wersalu do Paryża zadecydowały o zajęciu przez Burke’a pozycji zdecydowanie antyrewolucyjnej. Kolejne próby zmian politycznych i społecznych podejmowane przez rządy rewolucyjne utwierdziły jego stanowisko. Zob. F.P. Lock, op. cit., s. 243-257.

${ }^{6}$ Burke pisał o aggregate of nations, który słusznie nazywa się commonwealth. Zob. The Works of the Right Honourable Edmund Burke, t. 5, London 1887, s. 319. 
czych, które mogły zniszczyć panującą na kontynencie równowagę, oraz los kraju będącego jednym z najważniejszych elementów systemu europejskiego.

W wypadku rewolucji francuskiej autor Rozważań jako jeden z pierwszych przedstawicieli ówczesnego świata polityki dostrzegł w rozprzestrzeniającej się z Paryża fali groźbę zniszczenia zasad, które do tej pory uchodziły za fundamentalne dla tożsamości europejskiej ${ }^{7}$. Niebezpieczeństwo to Burke porównywał, z jednej strony, do inwazji barbarzyństwa, która zniszczyła cywilizację antyczną we wczesnych wiekach średnich, $\mathrm{z}$ drugiej zaś przypisywał mu cechy rewolucji religijnej, podobnej do tej, która podzieliła kontynent w XVI i XVII stuleciu. Było to więc, $\mathrm{w}$ jego opinii, podwójne zagrożenie, które mogło zniszczyć zarówno podstawy materialne Europy, jak i jej kościec kulturowy.

Sądzę, że zwrócenie uwagi na europejski kontekst Burke’owskiej interpretacji wydarzeń rewolucyjnych we Francji stwarza możliwość nowego spojrzenia na wiele intrygujących do dziś zagadnień związanych z wyobrażeniami na temat tego, czym jest Europa i co stanowi jej istotę. W szczególności interesujące byłoby uzyskanie odpowiedzi na pytania dotyczące tego, jak autor Rozważań postrzegał wspólnotę europejską w sytuacji kryzysowej, jakie idee uważał za najistotniejsze dla jej tożsamości oraz jak jego refleksja w tym aspekcie sytuowała się na tle współczesnych mu wyobrażeń o Europie. Kwestią wyjątkowo zajmującą wydaje się także rozstrzygnięcie, czy sposób postrzegania Europy przez Burke’a mógł stanowić uzasadnienie dla działań przeciwników rewolucyjnych koncepcji przebudowy kontynentu. Próby odpowiedzi na postawione pytania mogą okazać się ważne zwłaszcza dla współczesnych Europejczyków, gdyż dociekania na temat charakteru Europy, jej granic oraz części składowych stanowią dziś przedmiot licznych debat światopoglądowych, politycznych i naukowych.

Istnienie przestrzeni europejskiej było już oczywiste dla wielu osób zamieszkujących jej obszar w V i IV w. przed narodzeniem Chrystusa $^{8}$. Jednak w owym czasie Europy nie określano raczej poprzez to, czym jest, lecz czym różni się od innych regionów ${ }^{9}$. Jedną z cech, która miała znamionować Europejczyków, było dążenie do podobnych celów politycznych. Pomimo istnienia różnorodnych form państwowych wszystkie rządy akceptowały w zasadzie, że warunkiem tego, co starożytni Grecy określali mianem „dobrego życia”, jest wolność wyboru chroniona przez powszechny system prawa ${ }^{10}$. Dlatego od czasów Strabona aż po Monteskiusza ci, którzy mówili o istocie Europy, zazwyczaj łączyli ją z jakąś koncepcją wol-

7 Poza Rozważaniami o rewolucji we Francji tematyka europejska szeroko rozwijana była przez Burke'a w takich tekstach, jak: Thoughts on French Affairs (London 1791), Remarks on the Policy of the Allies (London 1793), Letters on a Regicide Peace (London 1795-1797), a także w korespondencji prowadzonej z licznymi przedstawicielami ówczesnego życia politycznego.

${ }^{8}$ Herodot zwracał uwagę na odmienne od perskiego europejskie traktowanie wolności. Zob. idem, Dzieje, przeł. i oprac. S. Hammer, t. 2, Warszawa 1959, s. 156.

9 A. Pagden, Introduction, [w:] The Idea of Europe: From Antiquity to the European Union, red. A. Pagden, Cambridge 2002, s. 3.

10 Ibidem, s. 4. 
ności ${ }^{11}$, która miała określać zamieszkujące ją społeczeństwa (uwaga ta dotyczy $\mathrm{w}$ szczególności autorów związanych $\mathrm{z}$ chrześcijaństwem łacińskim) ${ }^{12}$. To przekonanie było blisko związane z żywą w Europie od czasów antycznych tradycją republikańską i demokratyczną. Choć w średniowieczu i epoce nowożytnej większa część kontynentu pozostawała pod panowaniem monarchów, rządzący władcy akceptowali dwie podstawowe zasady: po pierwsze, że ich poddani są wolnymi osobami, niebędącymi ich własnością, po drugie, iż chociaż prawa mogą być wyrazem ich woli, podlegają oni wyższemu prawnemu porządkowi, który mógł być tworem Boga czy też - jak później przyjmowano - natury. Przekonanie owo w sposób znaczący ograniczało rządy książąt i królów. Inną cechą wyróżniającą Europę było przeświadczenie, że chociaż władza monarchów pochodzi od Boga, to jest im nadawana na mocy umów zawieranych $z$ ludem $^{13}$.

W sensie kulturowym od średniowiecza jedność kontynentu europejskiego opierała się na chrześcijaństwie, które także pośredniczyło w rozprzestrzenianiu się elementów klasycznej myśli i tradycji ku jego krańcom północnym i wschodnim. O dominującej roli chrześcijaństwa świadczy fakt, że społeczności zamieszkujące Europę określano jako wspólnotę chrześcijańską - respublica christiana. Renesans, a później reformacja spowodowały kryzys idei starego kontynentu opartej na religijnej jedności. Ponadto odkrycia geograficzne i podboje obszarów należących do innych kręgów cywilizacyjnych skłaniały do poszukiwań nowych sposobów wyrażania tożsamości europejskiej ${ }^{14}$.

W XVIII w. pytania o to, czym jest Europa, co decyduje o jej wyjątkowości i jaki jest jej zasięg, stanowiły temat licznych dzieł literackich i naukowych, a dyskusje o niej były czymś powszednim w ówczesnych salonach i stowarzyszeniach. Charakterystyczną cechą owych dysput było to, iż funkcjonowały w nich obok siebie zarówno opinie gloryfikujące dokonania polityczne oraz kulturowe Europy, jak i takie, które były krytyczne wobec jej osiągnięćc ${ }^{15}$.

Narodziny Europy oświeceniowi myśliciele mieli wiązać najczęściej z wyjściem ze średniowiecza i wyzwoleniem się spod wpływów papiestwa. Procesowi temu towarzyszyło kształtowanie się monarchii narodowych, ekonomiczny rozwój i rewolucja naukowa ${ }^{16}$. W sensie politycznym był to system państw, w którym raison

11 „Maraton oznacza zatem istotny zwrot w dziejach. Odtąd Europa — jako swoisty historyczny fenomen - wydaje się nierozdzielnie związana z ideami wolności i rozumu" - R. Buttigione, J. Marecki, Europa jako pojęcie filozoficzne, Lublin 1996, s. 48.

12 A. Pagden, op. cit., s. 4.

13 J. Baszkiewicz, Myśl polityczna wieków średnich, Warszawa 1970, s. 103-104; A.J. Carlyle, Political Liberty. A History of the Conception in the Middle Ages and Modern Times, Westport 1980.

14 J. Kieniewicz, Wprowadzenie do historii cywilizacji Wschodu i Zachodu, Warszawa 2003, s. 229-231.

15 E. Rostworowski, Europa oświeconych, [w:] Dziesięć wieków Europy. Studia z dziejów kontynentu, red. J. Żarnowski, Warszawa 1983, s. 147-149.

16 H. Seton-Watson, What is Europe, where is Europe? From mystique to politique, [w:] In Search of Central Europe, red. G. Schöpflin, N. Wood, Cambridge 1989, s. 33-34. 
détat i ius gentium zastąpiły średniowieczną teologię polityczną papiestwa i cesarstwa. Momentem wieńczącym formowanie się tej wspólnoty miał być, zdaniem oświeceniowych historyków, kończący wojnę o sukcesję hiszpańską traktat utrechcki z 1713 r. Wedle tej wizji Europa po zawarciu tego pokoju stanowiła republikę czy też konfederację równoważących ${ }^{17}$ się państw, podtrzymywaną przez różne układy sojusznicze. Elementem wzmacniającym ową konstrukcję miał być wprowadzany wszędzie na kontynencie za pośrednictwem handlu — system zasad wiodących do uformowania się europejskiej wspólnoty gospodarczej. Cechą charakterystyczną owej jedności miała być także tolerancja religijna ${ }^{18}$.

Gdyby wytyczyć europejski horyzont geograficzny oświecenia, musiałby się on rozpościerać od Atlantyku aż po Rosję, choć długo dla wielu nowożytnych myślicieli kraj ten $-\mathrm{z}$ racji swojej formy rządów (podobnie jak Turcja) - pozostawał poza granicami Europy. Próba modernizacji Rosji, podjęta przez Piotra I i kontynuowana przez Katarzynę II, spowodowała jednak, że w drugiej połowie XVIII w. państwo carów powszechnie traktowano już jako część Europy.

Problem Rosji, a w większym jeszcze stopniu kwestie związane z koloniami europejskimi w Ameryce ${ }^{19}$ skłoniły ówczesnych myślicieli do prób określenia kulturowej istoty europejskości. Owocem tych poszukiwań było, zdaniem Krzysztofa Pomiana, powstanie regulatywnej idei Europy ${ }^{20}$, w której jawiła się ona jako nadrzędna całość, której poszczególne państwa są niejako prowincjami i którym wspólne jest odrzucenie despotyzmu, czyli uznanie za wartości nadrzędne wolności i praworządności. Chodziło w szczególności o wolność sumienia i wolność słowa oraz wolność od samowoli, które były osiągalne dzięki prawu jako najważniejszemu regulatorowi stosunków między państwem i jednostkami, a także pomiędzy państwami. Takie rozumienie Europy było, według autora pracy Europa i jej narody, efektem ewolucji myśli po Rewolucji wspaniałej, a w szczególności kontynuowania jej tradycji na kontynencie przez Monteskiusza i Woltera. „Jedność europejska jawiła się w tej perspektywie jako oparta na wartościach świeckich, gdyż miała ona być odpowiedzią na niemal dwa wieki barbarzyńskich i bestialskich wojen religijnych" 21 . Dla Woltera, który zwracał uwagę na aspekt ideologiczny, Europa była tworem, który ukształtował się w momencie przejścia

17 By ową równowagę zapewnić, przeciwnicy Ludwika XIV wymusili na nim oraz jego wnuku Filipie zobowiązanie, które uniemożliwiało połączenie w przyszłości Francji i Hiszpanii pod jednym berłem. J.G.A. Pocock posunął się nawet do stwierdzenia, że w XVIII stuleciu „[t]he balance of power was »Europe« and »Europe« was the balance of power"; zob. idem, Some Europes in their history, [w:] The Idea of Europe..., s. 64.

18 H.D. Schmidt, The establishment of 'Europe' as a political expression, „The Historical Journal" 2, 1966, nr 9, s. 178.

19 Obszary zamieszkane przez Europejczyków w Ameryce traktowane były zwykle w XVIII i na początku XIX stulecia jako rozszerzenie Europy. Zob. S. Woolf, The construction of a European world-view in the revolutionary-Napoleonic years, „Past and Present” 1992, nr 137, s. 80.

20 K. Pomian, Europa i jej narody, Gdańsk 2004, s. 225.

${ }^{21}$ Ibidem. 
jej mieszkańców od religijnego fanatyzmu do oświeceniowej wspólnoty. Z owym oświeceniowym ideałem Europy współgrała idea postępu rozumianego jako powodowany naturalnymi przyczynami, stały, stopniowy i konieczny proces zmian wiodących ku określonemu, rozpoznawalnemu za pomocą rozumu celowi. Wyznacznikiem dokonującego się postępu miał być poziom odczuwanej przez lud lub naród wolności ${ }^{22}$.

Mimo świeckiego charakteru oświeceniowej koncepcji Europy można dostrzec, iż wielu osiemnastowiecznych myślicieli doceniało jej chrześcijańską spuściznę. Uwaga ta dotyczy, zdaniem Paula Hazarda, także autora Kandyda ${ }^{23}$ i znalazła swoje potwierdzenie w Encyklopedii. Autor poświęconego jej hasła, kawaler Luis de Jauccourt, zauważał, iż

nie jest ważne, że Europa jest najmniejszą z czterech części świata pod względem rozciągłości terytorium, skoro przewyższa wszystkie przez swój handel i żeglugę, przez swą urodzajność, przez oświecenie i przemyślność swych ludów, przez znajomość nauk, sztuk i rzemiosł, i — co najważniejsze - przez chrześcijaństwo, którego dobroczynna moralność dąży jedynie do uszczęśliwienia społeczeństwa. Tej religii zawdzięczamy w państwie pewne [lub niejakie - un ceretain] prawo polityczne, a w wojnie pewne [niejakie] prawo narodów [...]; przedstawiając jako swój cel jedynie nasze szczęście w życiu przyszłym, uszczęśliwia nas ona jeszcze w tym życiu ${ }^{24}$.

Na bazie akceptowanych przez wszystkich idei prawa natury, szacunku dla rozumu ludzkiego i dla doświadczenia oraz kultu antyku uformowała się w epoce oświecenia kosmopolityczna Europa elit. Tak pojmowana Europa - la république des lettres - stanowiła przede wszystkim własność salonów i w dużej mierze była podporządkowana płynącym z Paryża wzorcom i modom. Europejczykiem-kosmopolitą

stawał się człowiek, który myślał na sposób francuski: wchodził do pewnego szczepu, należał do pewnego narodu, narodu, który obejmował ludzi kulturalnych wszystkich narodów i którego członkowie czuli się związani wspólnotą języka, a nawet życia ${ }^{25}$.

Ta unifikująca wizja Europy zaczęła jednak pod koniec XVIII stulecia napotykać coraz silniejszy opór, szczególnie ze strony rodzących i umacniających się nacjonalizmów. Dominacji francuskiego modelu nie akceptowano zupełnie w Anglii, lecz spotykał się on z coraz większym oporem także na terenie Niemiec i Włoch.

22 R. Nisbet, History of the Idea of Progress, New York 1980, s. 179.

23 Europa miała być „czymś w rodzaju wielkiej republiki podzielonej na wiele państw o różnych ustrojach: monarchicznych, mieszanych, arystokratycznych, ludowych; wszystkie jednak utrzymują ze sobą łączność, gdyż mają to samo podłoże religijne, te same zasady prawa państwowego, polityki, nieznane innym częściom świata" - Voltaire, Le Siècle de Luis XIV, rozdz. II, cyt. za: P. Hazard, Myśl europejska w XVIII wieku od Monteskiusza do Lessinga, przeł. H. Suwała, Warszawa 1972, s. 383.

${ }^{24}$ Encyclopédie ou Dictionnaire raisonné des sciences, des arts et des métiers, t. 6, Paris 1756, s. 211-212, cyt. za: E. Rostworowski, op. cit., s. 147-148.

25 P. Hazard, op. cit., s. 388. 
Owe resentymenty uwidoczniły się z całą mocą w okresie wojen, jakie toczyła rewolucyjna i napoleońska Francja z prawie wszystkimi państwami europejskimi. To właśnie wtedy, u progu ogarniającego kontynent wojennego chaosu, swoją wizję Europy przedstawił Edmund Burke.

Tym, co łatwo dostrzec w pismach i wypowiedziach angielskiego polityka, jest przede wszystkim to, że Europa była dla niego pojęciem zarówno geograficznym, politycznym, jak i kulturowym. Jeśli chodzi o pierwszy aspekt, to autor Rozważań - podobnie jak większość osiemnastowiecznych myślicieli - postrzegał Europę jako obszar rozciągający się od Półwyspu Iberyjskiego aż po Rosję. Taki sposób percepcji możemy zauważyć choćby w powstałym w grudniu $1791 \mathrm{r}$. pamflecie Thoughts on French Affairs. W tekście tym Burke, zastanawiając się nad reperkusjami francuskich wydarzeń, starał się przewidzieć ich wpływ na sytuację wszystkich państw europejskich. Wśród wymienionych krajów możemy odnaleźć też te, które leżą na obszarze pomiędzy Atlantykiem i Uralem.

Na tak określonym terytorium na przełomie XVII i XVIII stulecia uformowała się, jego zdaniem, polityczna wspólnota obejmująca wszystkie państwa europejskie $^{26}$. Była ona niezmiernie rozległa, a relacje wewnątrz niej miały charakter wysoce skomplikowany ${ }^{27}$. Burke uważał, iż jej powstanie było procesem długotrwałym, a momentami wieńczącymi go były pokój westfalski, próby powstrzymania ekspansji Ludwika XIV oraz wojna o sukcesję hiszpańską. Do owego systemu politycznego autor Rozważań włączył z racji europejskiego dziedzictwa także Stany Zjednoczone oraz hiszpańskie posiadłości w Ameryce ${ }^{28}$.

Trwałość owej wspólnoty była możliwa dzięki obowiązującej na jej obszarze zasadzie balance of powers. Jednak w prezentowanej przez Burke'a wersji system równowagi miał dość złożony charakter ${ }^{29}$. Jego trzon stanowiły cztery zasadnicze elementy:

1. the Great Middle balance, który odnosił się do Wielkiej Brytanii, Francji i Hiszpanii;

2. the balance of the North, tworzony przez państwa północne;

3. the balance, external and internal, of Germany (wewnętrzna i zewnętrzna równowaga Niemiec);

4. the balance of Italy (równowaga Włoch) ${ }^{30}$.

Elementem scalającym europejską konstrukcję były akceptowane przez wszystkie państwa i usystematyzowane dzięki wysiłkowi wielkich jurystów normy Corps Diplomatique. Na owych zasadach miały opierać się, zdaniem Burke’a, pokojowe

26 The Works..., t. 5, s. 319.

27 Ibidem, t. 4, s. 455.

28 Ibidem, t. 5, s. 423.

29 H. Bull, The Anarchical Society: A Study of World Order and Politics, London-New York-Basingstoke 1995, s. 95.

30 The Works..., t. 5, s. 442. 
i przyjacielskie relacje państw cywilizowanej Europy ${ }^{31}$. Wedle Petera J. Stanlisa wigowski polityk postrzegał normy prawa międzynarodowego w duchu siedemnastowiecznych jurystów Suareza i Grocjusza. Podobnie jak oni sądził, iż jego zasady należy rozpatrywać jako przeniesienie na płaszczyznę stosunków prawnych i politycznych pomiędzy państwami reguł uniwersalnego prawa naturalnego ${ }^{32}$.

Potwierdzona przez reguły prawa międzynarodowego równowaga europejska pod koniec XVIII w. znalazła się w głębokim kryzysie. Najpoważniejszym niebezpieczeństwem była dla niej z pewnością rewolucja francuska. Jednak - zdaniem Burke’a - jej załamanie nastąpiło wcześniej i związane było z rozbiorami Polski oraz gwałtownym wzrostem siły militarnej uczestniczących w nich państw. W 1772 r. na łamach Annual Register Burke pisał:

Obecny, dokonany przemocą rozbiór i podział Polski, bez pozoru wojny albo nawet odcienia prawomocności, powinien być rozważany jako pierwsze rzeczywiste naruszenie nowoczesnego systemu politycznego Europy. Nie jest tylko (mówią kontynentalni politycy) częściowym podważeniem konstytucji naszej wielkiej zachodniej republiki, ale oznacza w jednej chwili przyłożenie siekiery do jej korzenia, w taki sposób, który grozi zupełnym obaleniem całości ${ }^{33}$.

Konsekwencje owego wydarzenia trudno było przewidzieć, albowiem apetyty zaborców wydawały się niezaspokojone. „Polska była tylko śniadaniem, nie można znaleźć jednak wielu takich krajów. Gdzie zatem przyjdzie im spożywać obiad?”34 Jednakże dopiero ekspansja rewolucyjnej Francji, która zdaniem Burke’a stanowiła połączenie quasi-religijnego zelotyzmu i hegemonistycznych aspiracji jej przywódców, spowodowała upadek jedności europejskiej opartej na równowadze i odmienności tworzących ją społeczności.

W przeciwieństwie do wielu myślicieli oświecenia Burke doceniał zróżnicowanie świata i niechętny był wszelkim rozwiązaniom mającym charakter uniwersalny. $\mathrm{W}$ jego publicystyce i wystąpieniach parlamentarnych często można było dostrzec szacunek wobec różnych tradycji kulturowych oraz religijnych. W szczególności owo nastawienie uwidoczniło się w jego zaangażowaniu w dysputy na temat polityki brytyjskiej w Indiach oraz w oskarżeniu gubernatora Warrena Hastingsa o popełnienie nadużyć $\mathrm{w}$ administrowaniu tamtejszymi mieszkańcami. Mimo takiej postawy wydaje się, że był on przekonany o istnieniu daleko posuniętej kulturowej

31 „All this body of old conventions, composing the vast and voluminous collection called the Corps Diplomatique, forms the code or statute law, as the methodized reasonings of the great publicists and jurists form the digest and jurisprudence, of the Christian world. In these treasures are to be found the usual relations of peace and amity in civilized Europe" - The Works..., t. 5, s. 361.

32 P.J. Stanlis, Edmund Burke and the law of nations, „The American Journal of International Law" 47, 1953, nr 3, s. 398.

33 Annual Register or the View of the History, Politics, and Literature, for the Year 1772, red. E. Burke, t. 15, London 1773, s. 2, https://books.google.pl/books?id=yKcaZzMYRUsC\&pg=PA34\&hl= pl\&source $=$ gbs_toc_r\&cad=4\#v=onepage\&q\&f=false (dostęp: 9 września 2015); jeśli nie podano inaczej, tłum. R.R.

34 The Works..., t. 8, s. 455. 
odrębności Europy wobec innych cywilizacji oraz o postępującym, choć w sposób powolny, procesie zdobywania przez nią przewagi ${ }^{35}$. Wspomniane zjawisko miało charakter wyjątkowy i niezamierzony, tym bardziej że żadne z państw europejskich

nie powstało na podstawie systematycznego planu ani w zgodzie z jakimkolwiek projektem. Ponieważ ich konstytucje nie są usystematyzowane, nie są one nastawione na żaden szczególny cel, wyraźnie wyodrębniony i wypierający pozostałe. Ich cele są bardzo zróżnicowane i w pewnym sensie nieskończone ${ }^{36}$.

Źródeł wyjątkowości cywilizacji europejskiej Burke dopatrywał się przede wszystkim w roli, jaką na jej terenie odgrywało chrześcijaństwo, w podobieństwie stosowanych rozwiązań ustrojowych, w kontynuacji dziedzictwa prawa rzymskiego i germańskich wyobrażeń społecznych oraz w występujących na jej całym obszarze, mających korzenie w średniowieczu, instytucjach feudalnych. Pomimo dostrzegalnych lokalnie odmienności jej najważniejsze zasady pozostawały wszędzie u podstaw takie same, co prowadziło pochodzącego z Irlandii polityka do konstatacji, iż żadna osoba opuszczająca swój kraj i pozostająca nadal w Europie nigdy nie może czuć się całkowicie wyobcowana ${ }^{37}$.

W wypadku chrześcijaństwa autor Rozważań był głęboko przekonany, iż prawdy, jakie ono niesie, są w pełni zgodne z ludzką naturą ${ }^{38}$ oraz konieczne do właściwego funkcjonowania społeczeństwa.

Jeśli chodzi o religię należącą do naszego stylu życia, to wszystkie nasze prawa i instytucje wznoszą się na jej fundamencie. Ta zasada jest zauważalna w każdej czynności życia; i jeśli zostałaby odrzucona [...], wszystko musiałoby ulec zmianie stosownie do tego ${ }^{39}$.

35 E. Burke, O duchu i naturze rewolucji w odniesieniu do innych krajów, [w:] idem, O duchu i naturze rewolucji. Wybór pism, przeł. A. Wincewicz-Price, Kraków 2012, s. 298.

36 Ibidem.

37 „The nations of Europe have had the very same Christian religion, agreeing in the fundamental parts, varying a little in the ceremonies and in the subordinate doctrines. The whole of the polity and economy of every country in Europe has been derived from the same sources. [...] From all those sources arose a system of manners and of education which was nearly similar in all this quarter of the globe, and which softened, blended, and harmonized the colors of the whole. There was little difference in the form of the universities for the education of their youth, whether with regard to faculties, to sciences, or to the more liberal and elegant kinds of erudition. From this resemblance in the modes of intercourse, and in the whole form and fashion of life, no citizen of Europe could be altogether an exile in any part of it. There was nothing more than a pleasing variety to recreate and instruct the mind, to enrich the imagination, and to meliorate the heart. When a man travelled or resided, for health, pleasure, business, or necessity, from his own country, he never felt himself quite abroad" - The Works..., t. 5, s. 319-320.

38 „Wiemy, i jesteśmy z tego dumni, że człowiek jest z swej natury zwierzęciem religijnym, że ateizm przeciwny jest nie tylko rozumowi, ale także instynktom" - E. Burke, Rozważania o rewolucji we Francji i o debatach pewnych towarzystw londyńskich zwiąanych z tym wydarzeniem, wyrażone w liście, który miał zostać wysłany do pewnego gentlemana w Paryżu, przeł. D. Lachowska, Kraków 1994, s. 107.

39 The Writings and Speeches of Edmund Burke, red. P. Langdorf, t. 9, cz. 2, Oxford 1991, s. 119. Podobną opinię Burke przestawił wcześniej, pisząc, że „religia stanowi podstawę społeczeństwa obywatelskiego, źródło wszelkiego dobra i wszelkiej otuchy" - E. Burke, Rozważania..., s. 106. 
Jego zdaniem nakazy religijne w sposób niezmiernie istotny wpływają także na życie polityczne każdej społeczności, a ich oddziaływanie jest szczególnie ważne tam, „[g]dziekolwiek człowiek panuje nad człowiekiem”40. Pozwalają one bowiem obywatelom zabezpieczać ich wolność, budząc

[w]e wszystkich osobach dzierżących jakąkolwiek władzę głęboką bojaźń [...], że działają na mocy powierzonego im zaufania i będą musiały zdać sprawę ze sposobu, w jaki je spożytkowały, przed wielkim Mistrzem, Twórcą i Założycielem społeczeństwa ${ }^{41}$.

Uniwersalna i fundamentalna rola, jaką odgrywało chrześcijaństwo na kontynencie europejskim, powodowała, że Burke często określał zamieszkujące ją społeczności nawiązującym do średniowiecza terminem Christendom ${ }^{42}$.

Niezmiernie istotną cechą wyróżniającą Europę były też w jego opinii przyjęte na jej obszarze rozwiązania ustrojowe. W szczególności podkreślał rolę monarchii, która stanowiła dominujący model polityczny wśród państw europejskich. Różniła się ona zasadniczo od charakterystycznego dla innych części świata i państw antycznych despotyzmu. W przeciwieństwie do nich

[w]e wszystkich tych starych krajach to nie ludzie zmuszeni są do podporządkowania się państwu, lecz państwo zostało utworzone dla ludzi. Każde państwo dążyło nie tylko do osiągnięcia wszelkiego rodzaju korzyści społecznych, ale dbało też o dobrobyt poszczególnych jednostek ${ }^{43}$.

Wspomniany przez autora Rozważań brak podporządkowania jednostki państwu oraz uznanie jego służebnej roli tworzyły ład, który był „faktycznie, choć nieformalnie źródłem zakresu wolności osobistej w formach ustroju najbardziej jej nieprzyjaznych. Wolność ta istniała w systemach monarchii absolutnych w zakresie nieznanym dawnym państwom" 44 . Europejscy królowie byli ponadto powołani przez Opatrzność do utrzymywania równowagi pomiędzy interesami tworzących społeczeństwo korporacji. Podstawową zasadą funkcjonowania monarchii europejskiej zdaniem Burkea były reguły sukcesji ${ }^{45}$ i dopóki jej ustalenia były przestrzegane, nie podległa ona kontestowaniu. Co więcej, charakterystyczny dla świata europejskiego duch monarchizmu miał być obecny także w tych krajach, które formalnie stały się republikami ${ }^{46}$.

Wspólne dla całej Europy były również powstałe w średniowieczu instytucje feudalne. Kształtowały one jej porządek ekonomiczny i społeczny. W opinii Burke’a stanowiły swego rodzaju syntezę tradycji plemiennych i antycznych. „Miały

40 Ibidem, s. 109.

41 Ibidem.

42 J.M. Welsh, Edmund Burke and International Relations. The Commonwealth of Europe and the Crusade against the French Revolution, London 1995, s. 71.

43 E. Burke, O duchu i naturze rewolucji..., s. 298.

44 Ibidem, s. 298-299.

45 E. Burke, Rozważania..., s. 33.

46 The Works..., t. 5, s. 320. 
korzenie $\mathrm{w}$ starych germańskich czy gockich zwyczajach [...] a całość udoskonalana i porządkowana była w system i dziedzinę przez prawo rzymskie" ${ }^{\prime 7}$. Ich trwałość wzmacniał podobny system przekonań i uczuć, który miał swe źródła $\mathrm{w}$ dawnym rycerstwie. Znaczenie owych wartości było fundamentalne, bo

[t]o one określiły charakter nowożytnej Europy. To one wyróżniały ją, bez względu na formy rządów, i to wyróżniały korzystnie od państw Azji i zapewne tych państw, które rozkwitały w najwspanialszych okresach świata antycznego. To one, bez mieszania społecznych sfer, wytworzyły szlachetną równość i wpoiły ją wszystkim warstwom społecznym. [...] Bez odwoływania się do siły i nie napotykając na opór, zasady owe łagodziły zawziętość dumy i władzy, obligowały władców do poddania się delikatnemu jarzmu społecznego prestiżu, zmuszały autorytety do elegancji, a rządy panujące ponad prawami łagodziły dobrymi obyczajami ${ }^{48}$.

Ideały rycerskie (idea gentlemana) oraz duch religii były także odpowiedzialne za rozwój europejskiej wiedzy. Dzięki nim „[s]zlachta i duchowieństwo, z powołania i za sprawą mecenatu, umożliwiały rozwój nauki nawet pośród wojen i chaosu, także wówczas, gdy państwa znajdowały się jeszcze w zaczątkowej postaci”49. Dzięki powstałym w średniowieczu na Zachodzie normom i wzorcom nastąpił w późniejszym czasie rozkwit materialny Europy. Będące jego podstawą „handel, rzemiosło i przemysł, bóstwa naszych przejętych ekonomią polityków, same są zapewne wyłącznie tworami, wyłącznie rezultatami [...]. Z pewnością wyrosły one w tej samej atmosferze, w której wyrosła nauka" ${ }^{50}$.

Dziedzictwo, jakie tworzą powstałe w odległej przeszłości obyczaje, zdaniem Burke’a odgrywa także niezmiernie ważną rolę w kształtowaniu wspólnego europejskiego porządku prawnego ${ }^{51}$ i moralnego. Dzieje się tak, ponieważ

[z]wyczaje mają większe znaczenie niż prawa. Na nich opierają się w wielkiej mierze ustawy. Prawo dotyka nas od czasu do czasu w tym lub innym miejscu. Zwyczaje są tym, co nas irytuje lub uspokaja, psuje albo oczyszcza, podnosi albo poniża, barbaryzuje albo uszlachetnia, przez stabilne, długotrwałe, jednolite i niedostrzegalne oddziaływanie w sposób podobny do oddychania powietrzem. To one nadają formę i kolor naszemu życiu. Stosownie do ich jakości, wspomagają moralność, utrwalają ją, albo całkowicie ją niszczą ${ }^{52}$.

Wydaje się, że dla Burke’a to właśnie powstała w ciągu wieków wspólnota obyczajów i wartości stanowiła najsilniejszy zwornik europejskiej jedności. Fakt ten miał swe źródła w tym, że

[1]udzie nie są ze sobą związani za pomocą umów i pieczęci. Tym, co ich prowadzi do jedności, są podobieństwa, zgodności i sympatie. Z narodami jest tak jak z jed-

47 Ibidem.

48 E. Burke, Rozważania..., s. 93-94.

49 Ibidem, s. 96.

50 Ibidem.

51 „It is virtually one great state, having the same basis of general law, with some diversity of provincial customs and local establishments" - The Works..., t. 5, s. 319.

52 Ibidem, s. 311. 
nostkami. Nic nie jest tak silne jak więź pomiędzy narodami, która nawiązuje się w prawach, zwyczajach, sposobach życia. Są one trwalsze niż siła traktatów. Są zobowiązaniami zapisanymi w sercu. Zbliżają ludzi do siebie bez ich wiedzy i czasem wbrew ich zamiarom ${ }^{53}$.

Warto zauważyć, że zasadnicze elementy swego wyobrażenia o Europie Burke przedstawił w szczególnym momencie, jakim były rewolucja francuska i lawina wydarzeń, które pociągnęła za sobą. Jak wspomniałem, jego stosunek do wstrząsów mających miejsce za kanałem La Manche uległ szybkiej krystalizacji. Początkowo usiłował być chłodnym obserwatorem, jednak postępująca radykalizacja obozu rewolucyjnego, upadek burbońskiej monarchii i wybuch wojen rewolucyjnych spowodowały, iż dostrzegł w wydarzeniach we Francji zagrożenie dla całego kontynentu. W znacznej mierze wynikało ono z pozycji, jaką zajmowało dawne mocarstwo Ludwików w Europie, oraz było skutkiem oddziaływania ideologicznego nowego reżimu. O ile ekspansja terytorialna rewolucyjnej Francji mogła być postrzegana w kategoriach politycznych jako naruszenie zasady balance of powers i powstrzymana dzięki tradycyjnej współpracy mocarstw europejskich, o tyle o wiele większym problem była rewolucyjna ideologia. Jej zyskujące popularność w wielu miejscach Europy zasady stanowiły zagrożenie podobne do reformacji, która podzieliła kontynent w XVI stuleciu.

Z tego też powodu jednym z najważniejszych kroków mających zaradzić rozprzestrzeniającym się z Paryża ideom było ukazanie ich prawdziwej natury i ostrzeżenie społeczeństw europejskich ${ }^{54}$. Wedle Burke’a, wbrew zadekretowanym w Deklaracji Praw Człowieka i Obywatela hasłom, prawdziwymi fundamentami rewolucji były sprzeczne z dziedzictwem europejskim królobójstwo, jakobinizm oraz ateizm ${ }^{55}$. Pierwsza zasada oznaczała w praktyce zakwestionowanie całego porządku monarchicznego jako niemającego sankcji demokratycznej. Dlatego też jej realizacja musiała prowadzić do uznania wszystkich władców za uzurpatorów i w konsekwencji rodziła konieczność unicestwienia ich wraz z rodzinami. Poprzez jakobinizm Burke rozumiał swego rodzaju bunt „przedsiębiorczych talentów” przeciwko panującym od wieków instytucjom i prawom. Jego motorem napędowym miała być wzniecona w warstwach nieposiadających nienawiść do tych, którzy cieszyli się bogactwem. Dzięki owej wrogości władze w państwach miały przejąć opętane wiarą w teoretyczne dogmaty grupy intelektualistów marzących o radykalnych zmianach społeczno-politycznych ${ }^{56}$. Natomiast ateizm francuskich rewolucjonistów w oczach Burke’a polegał na odrzuceniu wiary w „Boga jako moralnego władcę

53 Ibidem, s. 318-319.

54 "That Revolution seems to have extended even to the constitution of the mind of man" - The Works..., t. 5, s. 176.

55 Ibidem, s. 309.

56 „These philosophers are fanatics; independent of any interest, which if it operated alone would make them much more tractable, they are carried with such an headlong rage towards every desperate trial that they would sacrifice the whole human race to the slightest of their experiments" - The Works..., t. 5, s. 216. 
świata" i połączonych z tym próbach likwidacji chrześcijaństwa. W miejsce dawnych wierzeń mieli oni ustanowić „bezbożne, bluźniercze, nieprzyzwoite teatralne obrządki, na cześć ich zepsutego, zdeprawowanego rozumu oraz wznieść ołtarze personifikujące ich skorumpowaną i krwawą republikę" 57.

Urzeczywistnienie założeń rewolucyjnego programu musiało także, zdaniem brytyjskiego polityka, podważyć całość dotychczasowego życia wspólnotowego, ponieważ „wszystkie ich nowe instytucje [...] uderzają w korzeń naszej społecznej natury” 58 . Są one „faktycznie odwróceniem, i to fundamentalnym odwróceniem wszystkich praw, które utrzymywały dotychczas życie obywatelskie we wszystkich systemach politycznych świata" 59 .

Dlatego, by zapobiec katastrofie, według Burke’a konieczna była wspólna i solidarna interwencja mocarstw, prowadzona nie po to, aby wzmocnić wpływy któregokolwiek z nich, ale aby obronić zasady, na których opierał się przez wieki europejski porządek.

Toczymy wojnę szczególnej natury. [...] Toczymy wojnę z systemem, który w swej istocie jest nieprzyjazny wobec wszystkich innych rządów, który opowiada się za pokojem albo wojną, jeśli pokój albo wojna najlepiej służą ich obaleniu. Toczymy wojnę z „uzbrojoną doktryną"60.

Owa walka, mająca wymiar krucjaty, była ze wszech miar sprawiedliwa, a jej wynik miał zdecydować o losach Europy.

Trudno powiedzieć, w jakim stopniu wezwania autora Rozważań przyczyniły się do umocnienia oporu wobec ofensywy zrodzonej we Francji ideologii rewolucyjnej. Faktem jest, że po śmierci Burke’a wiele jego ocen przyjętych zostało przez brytyjską opinię publiczną za oczywiste. Cieszyły się też sporym powodzeniem wśród francuskich emigrantów. Do jego kontrrewolucyjnego dziedzictwa odwoływało się także liczne grono twórców i myślicieli. Uwaga ta dotyczy takich pisarzy, jak angielscy „poeci jezior” czy środowisko romantyków niemieckich. Adam Müller posunął się nawet do stwierdzenia, że Burke przez przypadek był Brytyjczykiem, jego duch był niemiecki, a teorie, które po sobie pozostawił, miały wymiar uniwersalny ${ }^{61}$. Na obszarze byłego Świętego Cesarstwa Rzymskiego szczególne zainteresowanie wzbudzały uwagi dotyczące duchowej jedności Europy, zakorzenione w średniowiecznym chrześcijaństwie i ideach rycerskich. Do owych motywów wyjątkowo chętnie nawiązywali Novalis ${ }^{62}$ i jego literaccy naśladowcy, którzy na gruncie światopoglądowym sprzeciwiali się francuskiemu i napoleońskiemu imperializmowi będącemu w ich mniemaniu wytworem oświeceniowego racjonalizmu.

57 Ibidem, s. 309-310.

58 Ibidem, s. 313.

59 Ibidem, s. 211.

60 Ibidem, s. 251.

61 A. Müllers, Lebenszeugnisse, t. 1, Paderborn 1966, s. 306.

62 Novalis, Chrześcijaństwo albo Europa, [w:] Manifesty romantyzmu 1790-1830. Anglia, Niemcy, Francja, wyb. i oprac. A. Kowalczykowa, Warszawa 1975, s. 183-201. 
Wydaje się, że dla współczesnych Europejczyków w antyrewolucyjnej twórczości brytyjskiego polityka najbardziej cenne są przemyślenia dotyczące kulturowej jedności Europy oraz sformułowane przez niego obawy odnoszone do prób zakwestionowania fundamentów owej wspólnoty. W sytuacji gdy owe wartości są $\mathrm{z}$ wielu stron podważane, refleksja Burkẻa może stanowić inspirację do podjęcia skutecznej dyskusji dla tych, którzy nadal doceniają ich wagę w życiu społecznym i politycznym ${ }^{63}$.

\section{Bibliografia}

\section{Źródła}

Annual Register or the View of the History, Politics, and Literature, for the Year 1772, red. E. Burke, t. 15, London 1773, https://books.google.pl/books?id=yKcaZzMYRUsC\&pg=PA34\&hl=pl\&source= gbs_toc_r\&cad=4\#v=onepage\&q\&f=false.

Burke E., O duchu i naturze rewolucji w odniesieniu do innych krajów, [w:] idem, O duchu i naturze rewolucji. Wybór pism, przeł. A. Wincewicz-Price, Kraków 2012.

Burke E., Rozważania o rewolucji we Francji i o debatach pewnych towarzystw londyńskich związanych z tym wydarzeniem, wyrażone w liście, który miał zostać wysłany do pewnego gentlemana w Paryżu, przeł. D. Lachowska, Kraków 1994.

Herodot, Dzieje, przeł. i oprac. S. Hammer, t. 2, Warszawa 1959.

Müllers A., Lebenszeugnisse, t. 1, Paderborn 1966.

The Works of the Right Honourable Edmund Burke, t. 4, 5, 8, London 1887.

The Writings and Speeches of Edmund Burke, t. 9, cz. 2, red. P. Langdorf, Oxford 1991.

\section{Opracowania}

Baszkiewicz J., Myśl polityczna wieków średnich, Warszawa 1970.

Bull H., The Anarchical Society: A Study of World Order and Politics, London-New York-Basingstoke 1995.

Buttigione R., Marecki J., Europa jako pojęcie filozoficzne, Lublin 1996.

Carlyle A.J., Political Liberty: A History of the Conception in the Middle Ages and Modern Times, Westport 1980.

Encyclopédie ou Dictionnaire raisonné des sciences, des arts et des métiers, t. 6, Paris 1756.

Hazard P., Myśl europejska w XVIII wieku od Monteskiusza do Lessinga, przeł. H. Suwała, Warszawa 1972.

Kieniewicz J., Wprowadzenie do historii cywilizacji Wschodu i Zachodu, Warszawa 2003.

Korab-Karpowicz W.J., Nieświadomość tego, co zostało utracone, http://www.teologiapolityczna.pl/ julian-korab-karpowicz-nieswiadomosc-tego-co-zostalo-utracone.

Lock F.P., Edmund Burke, t. 1. 1730-1784, Oxford 1998.

Małłek E., Wojna pamfletów w Anglii 1790-1793: wokół traktatu Edmunda Burke'a Reflections on the revolution in France, Torun 1993.

Nisbet R., History of the Idea of Progress, New York 1980.

Novalis, Chrześcijaństwo albo Europa, [w:] Manifesty romantyzmu 1790-1830. Anglia, Niemcy, Francja, wyb. i oprac. A. Kowalczykowa, Warszawa 1975.

63 Ciekawym głosem w takiej dyskusji jest artykuł W. Juliana Korab-Karpowicza, Nieświadomość tego, co zostało utracone, http://www.teologiapolityczna.pl/julian-korab-karpowicz-nieswiadomosc-tego-co-zostalo-utracone (dostęp: 9 września 2015). 
O'Brien C.C., The Great Melody: A Thematic Biography and Commented Anthology of Edmund Burke, London 1992.

Pagden A., Introduction, [w:] The Idea of Europe: From Antiquity to the European Union, red. A. Pagden, Cambridge 2002.

Pocock J.G.A., Some Europes in their history, [w:] The Idea of Europe: From Antiquity to the European Union, red. A. Pagden, Cambridge 2002.

Pomian K., Europa i jej narody, Gdańsk 2004.

Rostworowski E., Europa oświeconych, [w:] Dziesięć wieków Europy. Studia z dziejów kontynentu, red. J. Żarnowski, Warszawa 1983.

Schmidt H.D., The establishment of 'Europe' as a political expression, „The Historical Journal” 2, 1966, nr 9.

Seton-Watson H., What is Europe, where is Europe? From mystique to politique, [w:] In Search of Central Europe, red. G. Schöpflin, N. Wood, Cambridge 1989.

Stanlis P.J., Edmund Burke and the law of nations, „The American Journal of International Law” 47, 1953, nr 3.

Welsh J.M., Edmund Burke and International Relations. The Commonwealth of Europe and the Crusade against the French Revolution, London 1995.

Woolf S., The construction of a European world-view in the revolutionary-Napoleonic years, „Past and Present" 1992, nr 137. 